\title{
NUMBERS OF CONFIRMED SYPHILIS CASES IN PREGNANT WOMEN IN BRAZIL BETWEEN 2009 AND 2013
}

\section{ORIGINAL ARTICLE}

BARROS, Yara Lorrane Souza de ${ }^{1}$, FECURY, Amanda Alves², OLIVEIRA, Euzébio de $^{3}$, DENDASCK, Carla Viana ${ }^{4}$, ARAÚJO, Maria Helena Mendonça de ${ }^{5}$, SOUZA, Keulle Oliveira da ${ }^{6}$, DIAS, Claudio Alberto Gellis de Mattos ${ }^{7}$

BARROS, Yara Lorrane Souza de. Et al. Numbers of confirmed syphilis cases in pregnant women in Brazil between 2009 and 2013. Revista Científica Multidisciplinar Núcleo do Conhecimento. Year 05, Ed. 11, Vol. 25, pp. 53-61. November 2020. ISSN:2448-0959, Access link in: https://www.nucleodoconhecimento.com.br/health/syphilis-cases, DOI: 10.32749/nucleodoconhecimento.com.br/health/syphilis-cases

\section{ABSTRACT}

Syphilis is a bacterial disease transmitted sexually from pregnant women with syphilis to the fetus. The diagnosis of syphilis in pregnant women is confirmed through the VDRL exam. The objective of this work is to show the numbers of confirmed cases of syphilis in pregnant women in Brazil, regarding the year of diagnosis, age group, regions of Brazil, residential area, type of test, classification and evolution between 2009 and 2013. Secondary data taken from from the IT department of SUS DATASUS (http://datasus.saude.gov.br). The greater number of tests allows better

\footnotetext{
${ }^{1}$ Mining technician, graduated from the Federal Institute of Amapá (IFAP).

${ }^{2}$ Biomedical, PhD in Tropical Diseases, Professor and researcher of the Course of Medicine at the Federal University of Amapá (UNIFAP).

${ }^{3}$ Biologist, Doctor in Topical Diseases, Professor and researcher of the Physical Education Course at the Federal University of Pará (UFPA).

${ }^{4}$ Theologian, PhD in Psychoanalysis, researcher at the Research and Studies Center Advanced - CEPA.

${ }^{5}$ Physician, Professor and researcher of the Medical Course at the Federal University of Amapá (UNIFAP).

${ }^{6}$ Sociologist, Master's student in Anthropic Studies in the Amazon, Member of the Research Group "Laboratory of Education, Environment and Health" (LEMAS / UFPA).

${ }^{7}$ Biologist, PhD in Theory and Research of Behavior, Professor and researcher of the Post-Graduate Program in Professional and Technological Education (PROFEPT), Federal Institute of Amapá (IFAP).
}

RC: 66650

Available in: https://www.nucleodoconhecimento.com.br/health/syphilis-cases 
treatment and a reduction in the number of cases. However, the lack of preventive care during sexual intercourse leads to an increase in cases, especially among women of reproductive age. Areas with a larger population have higher numbers of cases. The high variation of partners in these areas drives the increase in contamination. The type of test influences the numbers. Less specific, more general tests, find specific and non-specific antibodies to the bacteria. This can change the actual numbers. Female health care makes the diagnosis early, facilitating treatment. Syphilis is not directly responsible for the highest number of mortality in pregnant women.

Keywords: Epidemiology, syphilis, pregnant.

\section{INTRODUCTION}

Syphilis is a bacterial disease that affects the entire body, transmitted sexually; by blood donation; by direct contact with contaminated blood; and the pregnant woman with syphilis for the fetus. The bacterium that causes the disease is Treponema Pallidum (CARVALHO et al., 2014, JUNIOR et al., 2009; ROCHA et al., 2020)..

Syphilis symptoms appear in three stages. In the first phase, red spots may appear on the body, usually sores on the genitals. In the second phase, it is possible for the disease to lie dormant for a period of up to eight months, when the bacteria can spread, affecting the skin and organs. In the third phase, inflammation in the body's tissues, such as bones, muscles and liver, is common (AVELLEIRA et al., 2006; BRETAS et al., 2008).

The disease needs to be diagnosed so that the patient can make the appropriate treatment, preventing the transmission of the disease through the use of male / female condoms. The most effective treatment is the benzathine penicillin drug. Until 2015 there was no record of any case of resistance to it. Other drugs are used in the treatment of syphilis, but the one with the greatest efficiency in the treatment / cure is this type of penicillin (KALININ et al., 2015; BRASIL, 2015).

$\mathrm{RC}: 66650$

Available in: https://www.nucleodoconhecimento.com.br/health/syphilis-cases 
The diagnosis of syphilis in pregnant women is confirmed by VDRL (Venereal Disease Research Laboratory) during prenatal care. The discovery of the disease and the treatment of pregnant women during prenatal care with penicillin prevent congenital syphilis (SUTO et al., 2016; MESQUITA et al., 2012).

The number of syphilis cases in pregnant women in Brazil was 21382, in 2012 and 2013 (BRASIL 2015).

The number of syphilis cases in pregnant women in the Northeast was 4,433, in 2012 and 2013. In the same period, the number of syphilis cases in pregnant women in the Southeast was 10,052; in the South it was 2795; in the Midwest it was 1961; and in the North it was 214 (BRASIL 2015).

The number of syphilis cases in pregnant women in Amapá was 176, in 2012 and 2013 (BRASIL 2015).

\section{AIM}

The objective of this article is to show the numbers of confirmed cases of syphilis in pregnant women in Brazil, regarding the year of diagnosis, age group, regions of Brazil, residential area, type of test, classification and evolution between 2009 and 2013.

\section{METHOD}

Data taken from the SUS IT department - DATASUS (http://datasus.saude.gov.br) following the following steps: first, the "access to information" tab was selected, followed by the "health information (TABNET)" option. "Shortly afterwards the option" epidemiological and morbidity ". We clicked on the option "Diseases and Notifiable Diseases From 2007 onwards (SINAN)" and then "Syphilis in Pregnant Women", and in the "geographical scope" tab, selected "Brazil by Region, State and Municipality". The next steps were: A) in the line "Cases confirmed according to Year of Diagnosis"

RC: 66650

Available in: https://www.nucleodoconhecimento.com.br/health/syphilis-cases 
were selected, in the column "not active" and in the content "confirmed cases". For this option and for the others below, the data were collected in the period from 2009 to 2013. B) in the line "Confirmed cases according to Notification region" was selected, in the "not active" column and in "confirmed cases" content. C) in the line, "Cases confirmed by age group" were selected, in the column "not active" and in content "confirmed cases". D) in the line "Cases confirmed according to Evolution" were selected, in the column "not active" and in content "confirmed cases". E) in the line, "Cases confirmed according to clinical classification" were selected, in the column "not active" and in content "confirmed cases". F) in the line "Cases confirmed according to Non-Trep Test" were selected, in the column "not active" and in content "confirmed cases". G) in the line "Cases confirmed according to Trep Test" were selected, in the column "not active", in the content "confirmed cases". H) in the row select "Cases confirmed by Residence Zone according to Year of Diagnosis", in the column select "Residential Area" and in content "confirmed cases". The data was compiled using the Excel application, part of the Microsoft Corporation Office suite. The bibliographic research was carried out on scientific articles, using computers from the computer lab of the Federal Institute of Education, Science and Technology of Amapá, Campus Macapá, located at: Rodovia BR 210 KM 3, s / n - Bairro Brasil Novo . CEP: 68.909-398, Macapá, Amapá, Brazil.

\section{RESULTS}

Figure 1 shows the number of confirmed syphilis cases in pregnant women per year in Brazil between the years 2009 to 2013. The data shows an increase in the number of confirmed cases from 2009 to 2012 . This number dropped by half in the year 2013 when compared to the previous year.

$\mathrm{RC}: 66650$

Available in: https://www.nucleodoconhecimento.com.br/health/syphilis-cases 
Figure 1 Number of confirmed cases of syphilis in pregnant women per year in Brazil between the years 2009 to 2013 .

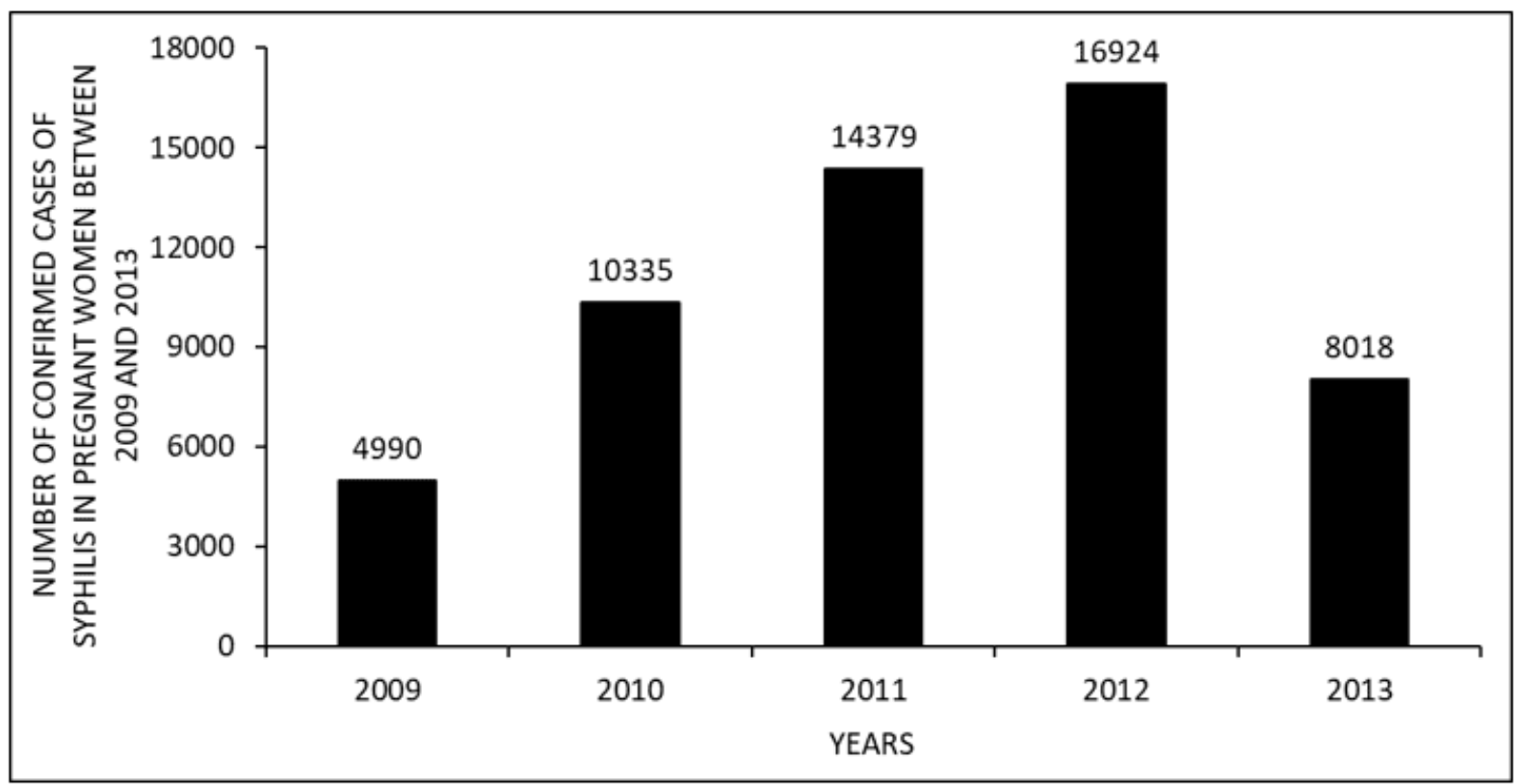

Figure 2 shows the number of confirmed syphilis cases in pregnant women by age group in Brazil between the years 2009 to 2013. Between 10 and 39 years of age there was an increase. This number decreases between 40 and 64 years of age.

RC: 66650

Available in: https://www.nucleodoconhecimento.com.br/health/syphilis-cases 
Figure 2 Number of confirmed syphilis cases in pregnant women by age group in Brazil between the years 2009 to 2013 .

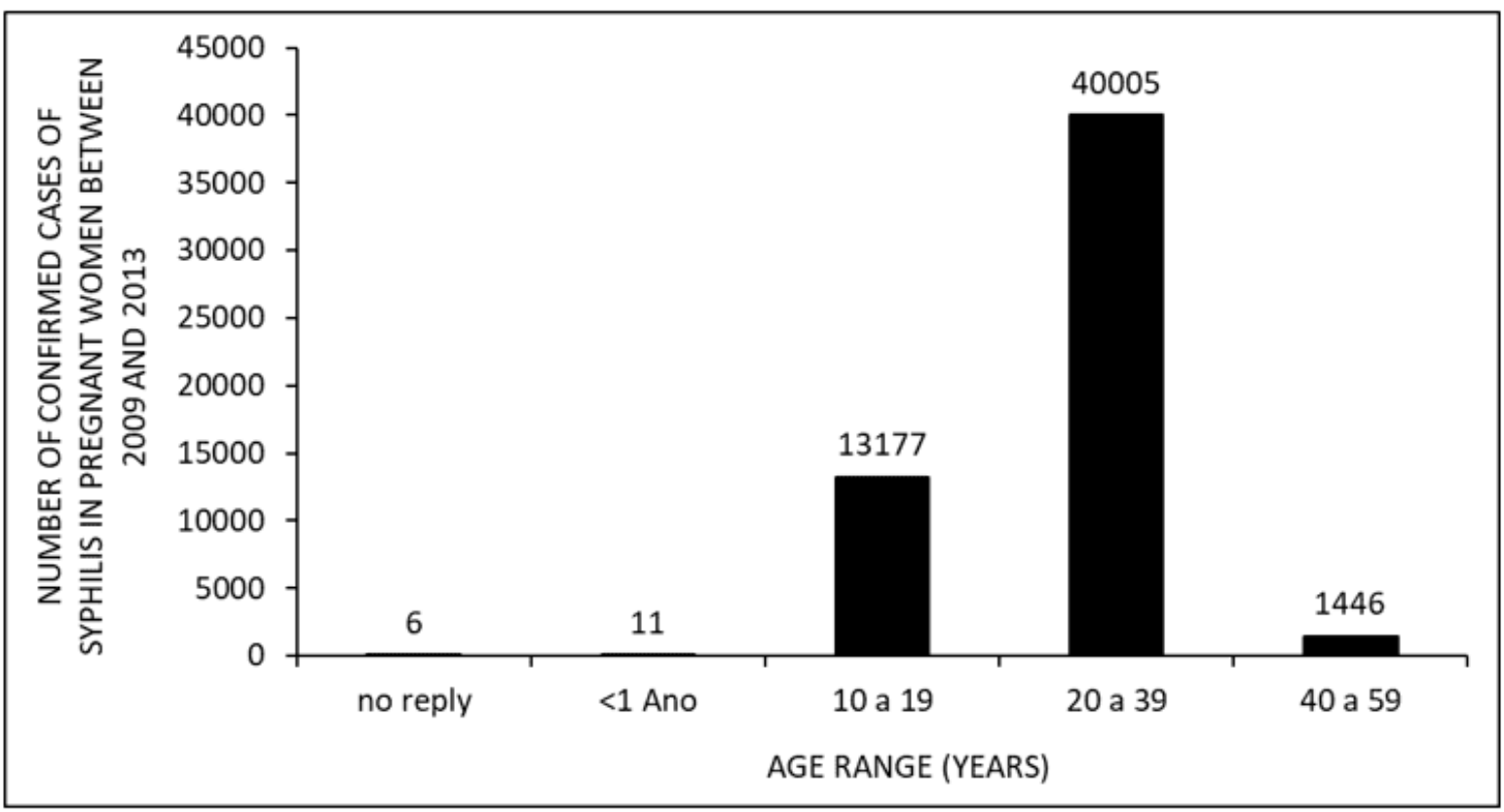

Figure 3 shows the number of confirmed syphilis cases in pregnant women by region in Brazil between the years 2009 to 2013. The southeast region has the largest number of confirmed cases, followed respectively by the northeast, north, south and midwest regions.

RC: 66650

Available in: https://www.nucleodoconhecimento.com.br/health/syphilis-cases 
Figure 3 Number of confirmed cases of syphilis in pregnant women by region of the country in Brazil between the years 2009 to 2013.

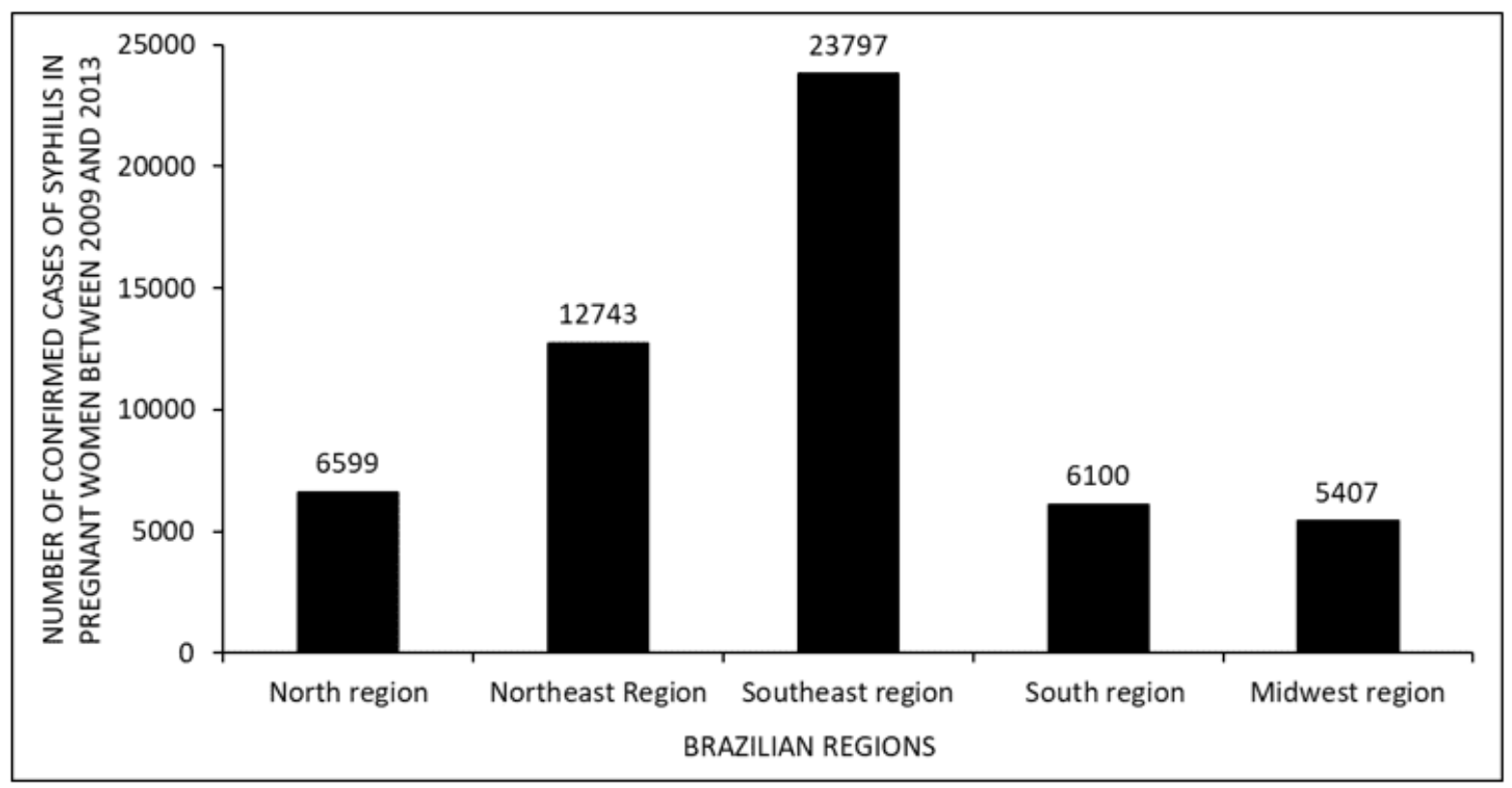

Figure 4 shows the number of confirmed cases of syphilis in pregnant women by area of residence in Brazil between the years 2009 to 2013. The number in the urban area is approximately 8 times higher than in the rural area. The smallest number of cases per area of residence is periurban and no reply, respectively.

RC: 66650

Available in: https://www.nucleodoconhecimento.com.br/health/syphilis-cases 
Figure 4 Number of confirmed syphilis cases in pregnant women according to the type of area of residence in Brazil between 2009 and 2013.

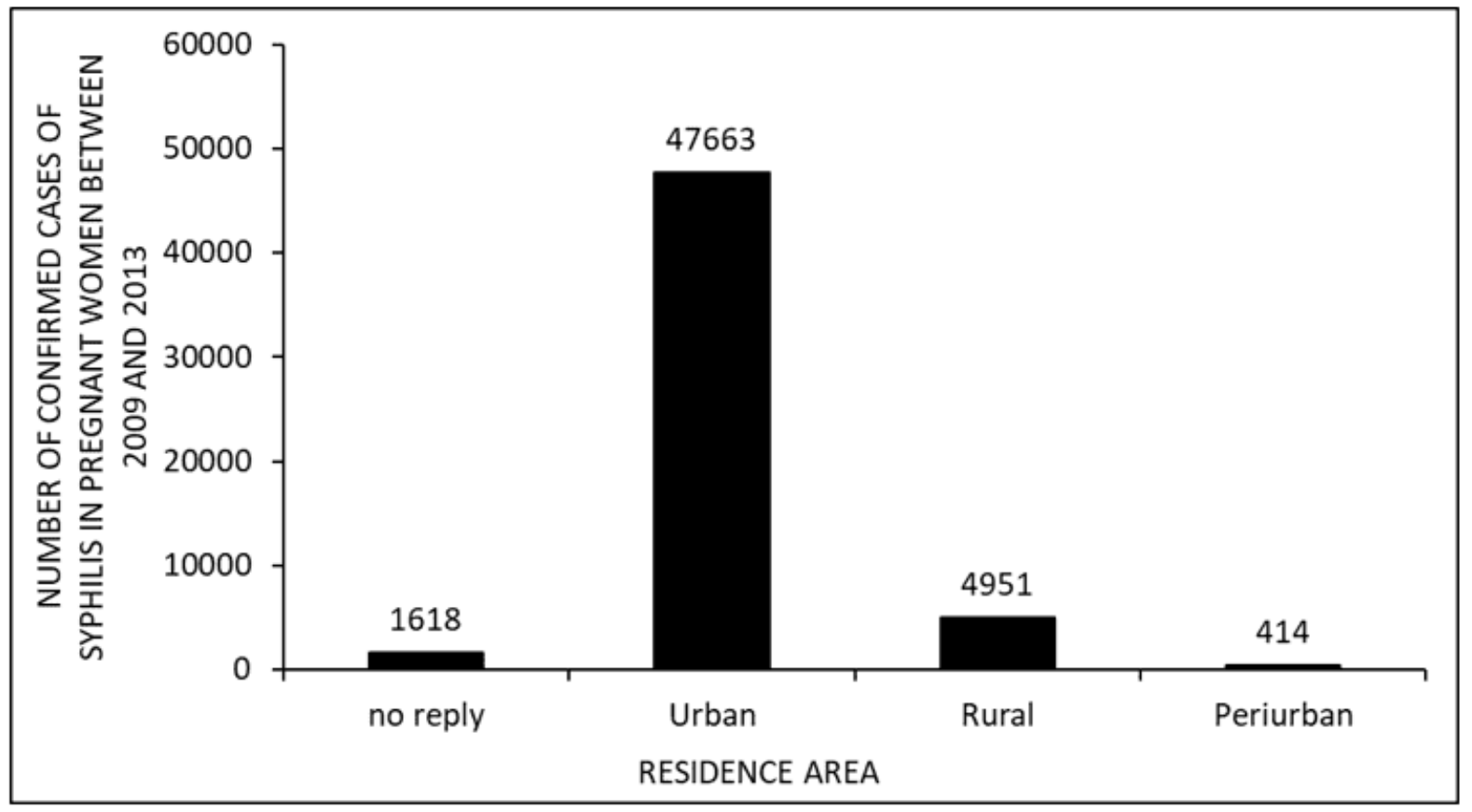

Figure 5 shows the number of confirmed cases of syphilis in pregnant women by type of test performed in Brazil between the years 2009 to 2013. The number of cases of tests performed Ign / whites per TREP test is four times higher than NON TREP tests. The number of reactive cases by NON TREP tests is almost double that of reactive cases by TREP tests. The number of non-reactive cases between NONTREP and TREP tests are approximate. The number of cases not performed by TREP tests is nine times greater than the number of cases not performed by nonTREP tests.

RC: 66650

Available in: https://www.nucleodoconhecimento.com.br/health/syphilis-cases 
Figure 5 Number of confirmed cases of syphilis in pregnant women according to the type of test performed in Brazil between the years 2009 to 2013.

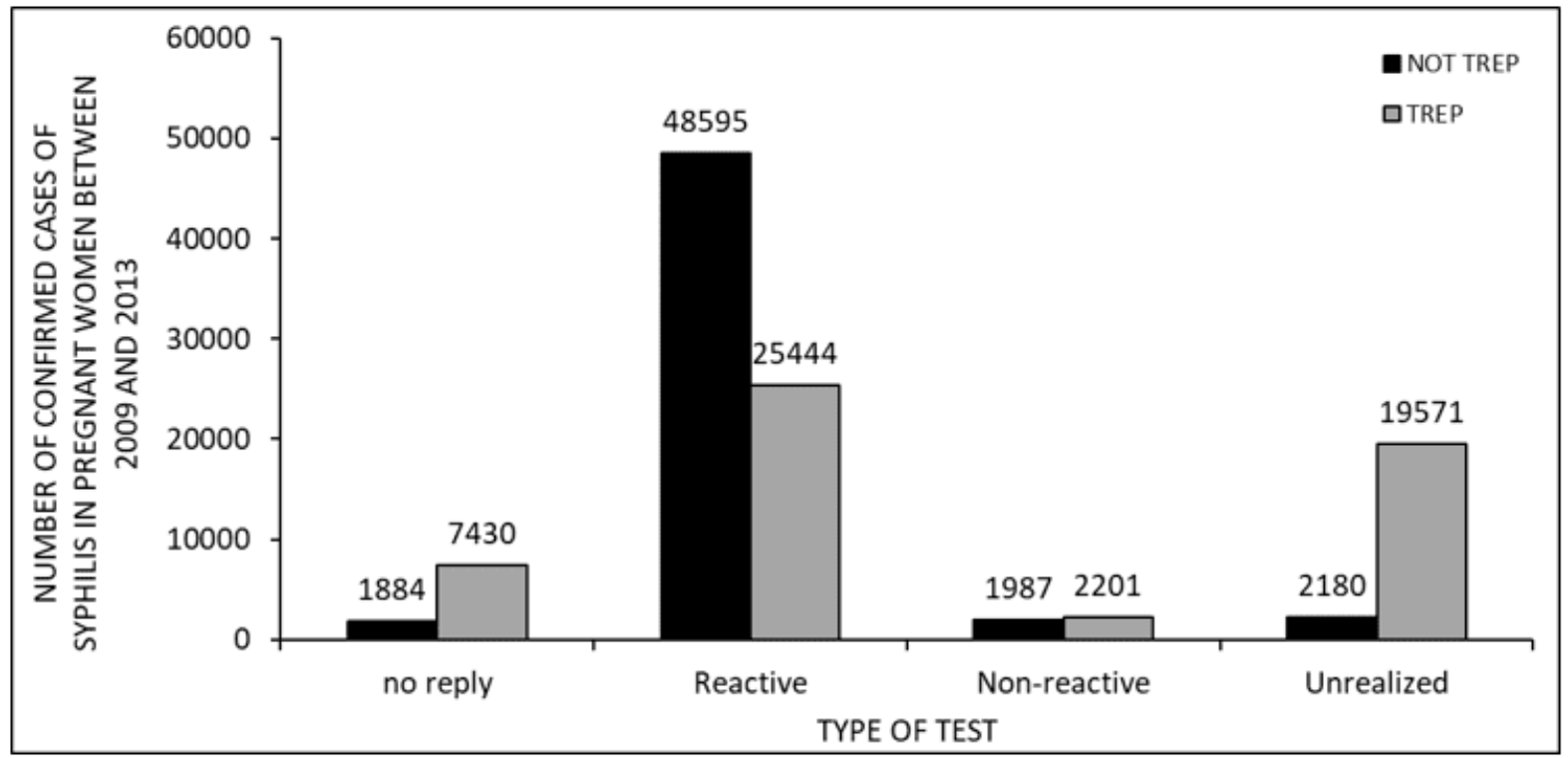

Figure 6 shows the number of confirmed syphilis cases in pregnant women according to the classification in Brazil between the years 2009 to 2013. The primary classification has the highest number of cases, followed respectively by no reply and latent. The classifications, secondary and tertiary, have the fewest confirmed cases.

RC: 66650

Available in: https://www.nucleodoconhecimento.com.br/health/syphilis-cases 
Figure 6 Number of confirmed cases of syphilis in pregnant women according to the classification in Brazil between the years 2009 to 2013.

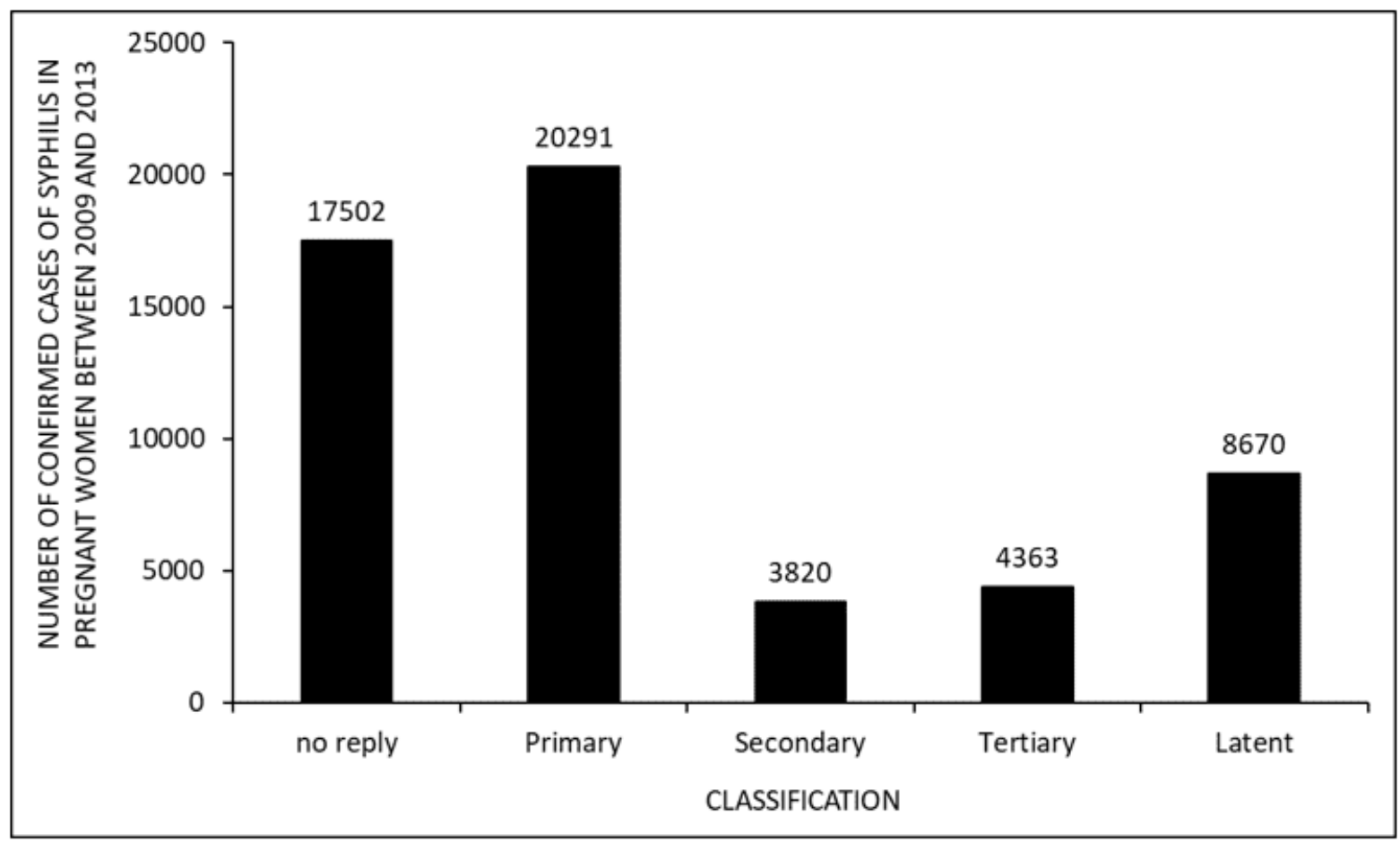

Figure 7 shows the number of confirmed syphilis cases in pregnant women according to the evolution in Brazil between the years 2009 to 2013. The data show that the number of deaths of pregnant women who acquired syphilis in this period was twice the number of cures. The greatest number of deaths occurred due to other causes. The lowest number of deaths in the period appeared as under investigation.

RC: 66650

Available in: https://www.nucleodoconhecimento.com.br/health/syphilis-cases 
Figure 7 Number of confirmed cases of syphilis in pregnant women according to the evolution in Brazil between the years 2009 to 2013.

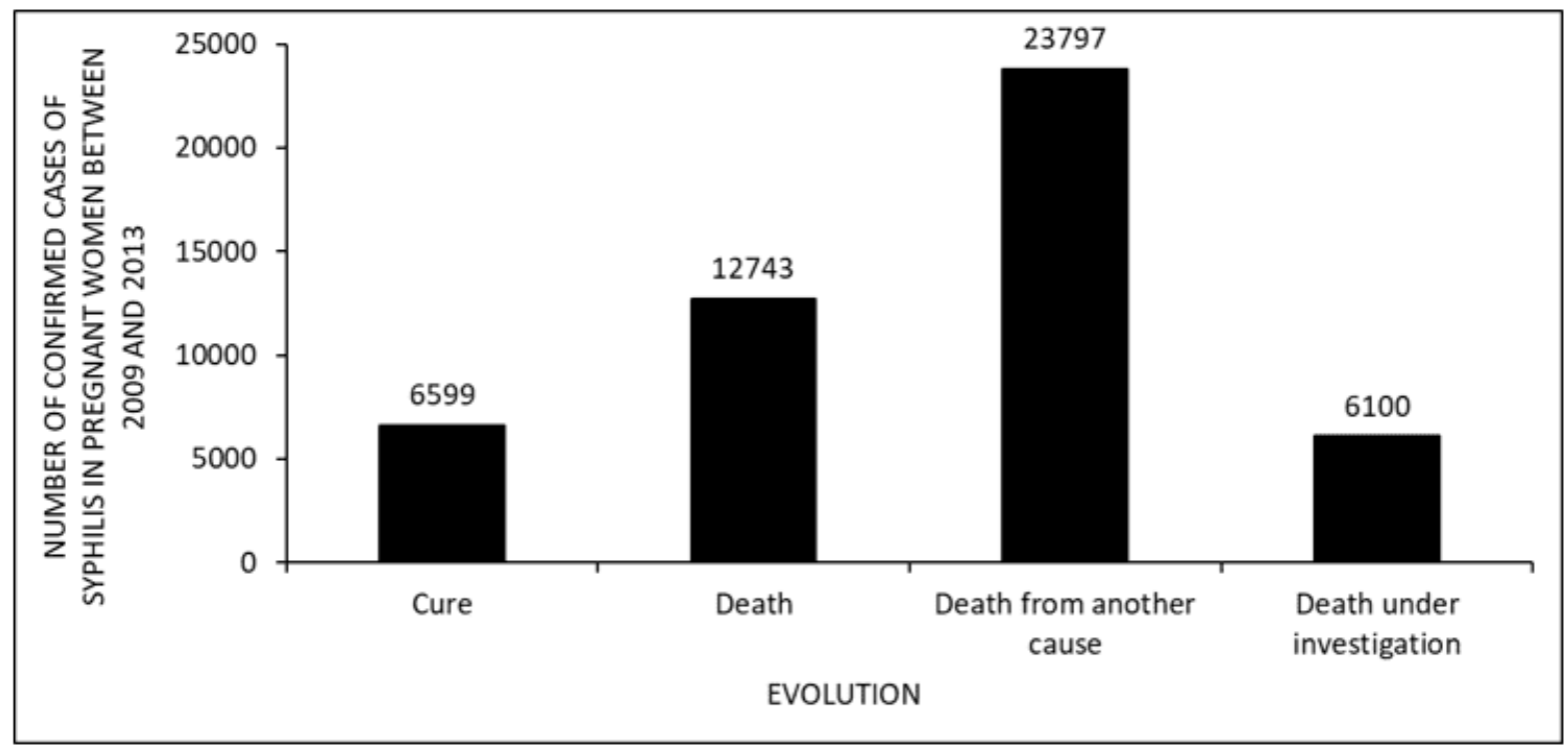

\section{DISCUSSION}

There was an increase in the number of confirmed syphilis cases in pregnant women between the years 2009 to 2012. Between 2011 and 2013 there was an increase in the number of exams, from 31,500 to 1.7 million, which seems to have enabled the treatment of the patient with syphilis. This scenario may have influenced the drop in confirmed cases in pregnant women in 2013 (BRASIL, 2013; 2017).

The data show cases of syphilis in pregnant women increased between 10 and 39 years old and its decrease between 40 and 64 years old (figure 2), corroborated by the literature. In the 20-34 age group, women are at the peak of their reproductive phase. There seems to be a higher rate of pregnant women with syphilis in this age group, possibly explained by the practice of unprotected sex (COSTA et al, 2012).

The Southeast is the Brazilian region that has the highest number of syphilis cases in pregnant women in the surveyed period. This data can be explained by the fact that the Southeast concentrates most of the Brazilian population and approximately half

RC: 66650

Available in: https://www.nucleodoconhecimento.com.br/health/syphilis-cases 
of the population admits not to use condoms during sexual relations (BRASIL, 2011; IBGE, 2010).

The urban area of Brazil presented, in the studied period, a greater number of cases of pregnant women with syphilis when compared to the rural area (Figure 4). According to the literature, people in the urban population have sex with a greater number of partners. This can lead to an increase in the probability of an individual without a stable or fixed sexual partner to acquire sexually transmitted infections such as syphilis (BRASIL, 2011).

The largest number of confirmed cases was in the NON TREP tests than in the TREP tests. This probably occurred because the TREP tests are more specific by locating only antibodies to the bacteria, while the NON TREP tests find specific and non-specific antibodies to the bacterium Treponema pallidum (BRASIL, 2015).

There was a high number of confirmed syphilis cases in pregnant women by primary classification. It is assumed that after the first symptom, in the case of hard cancer, the patient seeks hospital care when she is diagnosed with primary syphilis (AVELLEIRA et AL, 2006).

The highest number of deaths in pregnant women with syphilis was due to another cause. According to the literature, more than half of maternal deaths worldwide were due to hemorrhage, hypertension and septsemia (SAY, 2014).

\section{CONCLUSION}

The greater number of tests allows better treatment and a reduction in the number of cases. However, the lack of preventive care during sexual intercourse leads to an increase in cases, especially among women of reproductive age.

Areas with a larger population have higher numbers of cases. The high variation of partners in these areas drives the increase in contamination.

RC: 66650

Available in: https://www.nucleodoconhecimento.com.br/health/syphilis-cases 
The type of test influences the numbers. Less specific, more general tests, find specific and non-specific antibodies to the bacteria. This can change the actual numbers. Female health care makes the diagnosis early, facilitating treatment.

Syphilis is not directly responsible for the highest number of mortality in pregnant women.

\section{REFERENCES}

AVELLEITA, J. C. R.; BOTTINO, G; Sífilis: Diagnóstico, Tratamento e Controle. An. Bras. Dermatol, Vol.81 no.2 Rio de Janeiro Mar./Apr. 2006.

BRASIL São Paulo, Centro de Referência e Treinamento DST/Aids. Boletim Epidemiológico. Ano XXX. 2013.

BRASIL, Ministério da Saúde. Secretaria de Ciência, Tecnologia e Insumos Estratégicos. Relatório de Recomendação, n¹59, 2015. Disponível em: <file://C:/Users/aluno.SELABI/Desktop/CURSO\%20DE\%20ESCRITA/(BRASIL,\%20 2015).pdf>. Acesso em:26/09/2017.

BRASIL. Ministério da Saúde Secretaria de Vigilância em Saúde - Departamento de DST, Aids e Hepatites Virais SAF SUL Trecho 2 Boletim Epidemiológico - Sífilis Ano IV- ํㅜ 1, 2015.

BRASIL. Ministério da Saúde. Ministério da Saúde Lança Campanha de Combate à Sífilis. Disponível em: <http://www.brasil.gov.br/saude/2013/10/ministerio-dasaude-lanca-campanha-de-combate-a-sifilis>. Acesso em: 19/09/2017.

BRASIL. Ministério da Saúde. Portal da Saúde. Combate á Sífilis Congênita. Disponivel em: <http://portalarquivos.saude.gov.br/campanhas/sifilis/>. Acesso em: 19/09/2017.

RC: 66650

Available in: https://www.nucleodoconhecimento.com.br/health/syphilis-cases 
BRASIL. Ministério da Saúde. Secretaria de Vigilância em Saúde. Departamento de DST, Aids e Hepatites Virais. Pesquisa de conhecimento, atitudes e práticas na população brasileira / Ministério da Saúde. Secretaria de Vigilância em Saúde. Departamento de DST, Aids e Hepatites Virais. - Brasília: Ministério da Saúde, 2011.

BRASIL. Ministério da Saúde. Secretaria de Vigilância em Saúde. Departamento de DST, Aids e Hepatites Virais. Pesquisa de conhecimento, atitudes e práticas na população brasileira / Ministério da Saúde. Secretaria de Vigilância em Saúde. Departamento de DST, Aids e Hepatites Virais. - Brasília: Ministério da Saúde, 2011.

BRETAS, J. R. S.; OHARA, C. V. S.; JARDIM, D. P.; MUROYA, R. L.; Conhecimento Sobre DST/AIDS por Estudantes Adolescentes. Rev. esc. enferm. USP vol.43 no.3 São Paulo Sept. 2009.

CARVALHO, I. S.; BRITO, R. S; Sífilis congênita no Rio Grande do Norte: estudo descritivo do período 2007-2010. Epidemiol. Serv. Saúde, v.23 n.2 Brasília, 2014.

COSTA, C. C.; FEITAS, L. V.; SOUSA, D. M. N.; OLIVEIRA, L. L.; CHAGAS, A. C. M. A.; LOPES, M. V. O.; DAMASCENO, A. K. C. Sífilis Congênita No Ceará: Análise Epidemiológica De Uma Década. Rev Esc Enferm USP 2013; 47(1):149-56.

IBGE, Censo Demográfico 1960, 1970, 1980, 1991, 2000 e 2010. Disponível em: $<$ https://censo2010.ibge.gov.br/sinopse/index.php?dados=8>. Acesso em: 26/09/2017.

JUNIOR, W. B.; SHIRATSU, R.; PINTO, V.; Abordagem nas Doenças Sexualmente Transmissíveis. An Bras Dermatol. 2009;84(2):151-59.

KALININ, Y.; NETO, A. P.; PASSARELLI, D. H. C. Sífilis: aspectos clínicos, transmissão, Manifestações orais, diagnóstico e tratamento. Odonto 2015; 23(4546): 65-76.

RC: 66650

Available in: https://www.nucleodoconhecimento.com.br/health/syphilis-cases 
MESQUITA, K.; LIMA, G. K.; FILGUEIRA, A.; FLÔR, S. M.; FREITAS, C. A.; LINHARES, M. S.; GUBERT, F.Análise dos Casos de Sífilis Congênita em Sobral, Ceará: Contribuições para Assistência Pré-Natal. DST - J bras Doenças Sex Transm 2012; 24(1):20-27

ROCHA, K.D., FECURY, A.A., OLIVEIRA, E., DENDASCK, C.V., DIAS, C.A.G.M. Number of congenital syphilis cases in Brazil between 2009 and 2013. Revista científica Multidisciplinar Núcleo do Conhecimento. Year 05, Ed. 05, Vol. 01, pp. 131-143. May 2020. ISSN:2448-0959. DOI: 10.32749/nucleodoconhecimento.com.br/health/congenital-syphilis-cases.

SAY, L.; CHAU, D.; GEMMILL, A.; TUBÇALP, O.; MOLLER, A.; DANIELS, J.; GULMEZOGLU, A. M.; TEMMERMAN, M.; ALKEMA, L. Global Causes Of Maternal Death: A Who Systematic Analysis. Lancet Glob Health, Vol.2, 2014.

SUTO, C. S. S.; SILVA, D. L.; ALMEIDA, E. S.; COSTA, E. L.; EVANGELISTA, T. J. Assistência Pré-Natal A Gestante Com Diagnóstico De Sífilis Revista de Enfermagem e Atenção à Saúde 2016; 5(2): 18-33.

Submitted: November, 2020.

Approved: November, 2020.

RC: 66650

Available in: https://www.nucleodoconhecimento.com.br/health/syphilis-cases 